\title{
Keeping the records straight: The literary afterlife of three Boer generals
}

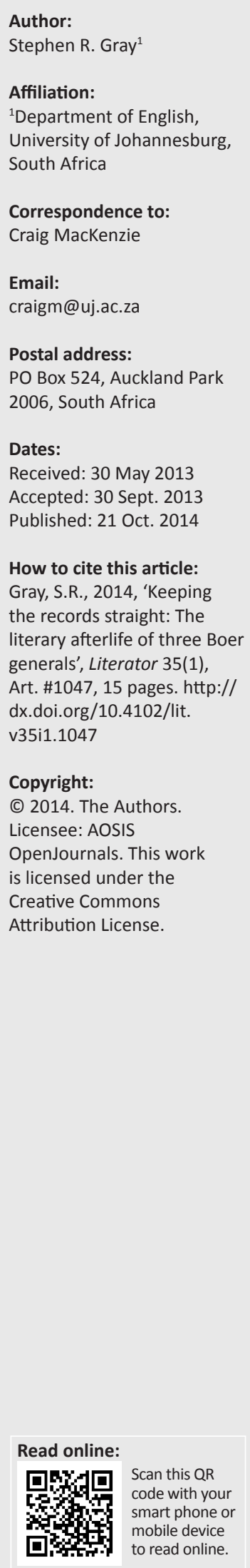

The intention of this article is to highlight some overlooked or lesser-known facets of the remarkable biographies of three Boer generals (Cronjé, Viljoen and De Wet). They achieved fame, particularly in the English-language media and publishing circles, immediately after the Second Anglo-Boer War. Whilst their reputations in the written literature are unassailable and of recurring interest, perhaps some over-mythologising has been responsible for occasional distortions which render their superb life stories less satisfying. The surprising and unexpected aftermath of such details in the subsequent records is also noted.

Om by die ware feite te bly: Die literêre nagedagtenis van drie boeregeneraals. Die doel van hierdie artikel is om sommige van die misgekykde of minder bekende fasette van die merkwaardige biografieë van drie boeregeneraals (Cronjé, Viljoen en De Wet) uit te lig. Hulle het veral in die Engelse media en uitgewersbedryf roem verwerf direk na die Tweede Angloboereoorlog. Alhoewel hulle reputasie onbetwisbaar is en blywende belangstelling in die geskrewe literatuur ontvang, is die ietwat oordrewe mitologisering daarvan moontlik verantwoordelik vir die sporadiese wanvoorstellings wat hulle uitsonderlike lewensverhale minder bevredigend weergee. Daar word ook gelet op die verrassende en onverwagte nadraai van sodanige detail in latere vermeldings daarvan.

The recently published historical work by Sonja Loots called Sirkusboere (2011) has renewed an interest in the Second Anglo-Boer War of 1899-1902. A brilliant recreation of key events of the period, it is not only a wrenchingly human read, but an impeccably researched novel, as the many documentary sources cited in her acknowledgements make evident.

She focuses on the biographies of two well known generals, Piet Cronjé (b. 1836) and Ben Viljoen (b. 1868) of two different generations, who shared an exile as prisoners of war on St Helena. Subsequently both were then recruited by her superb third major character, the showman Frank Fillis, to recreate battle pieces of their downfall in a showbiz spectacular staged in the United States. This way Loots is able to meld familiar portraits with the bizarre and outrageous in order to speculate on the human implications of the newspaper coverage their desperate acts provoked, and hence how their reputations were manipulated for propagandistic ends, then and even nowadays. It is the handling of such literary aftermaths which are the topic here.

Then in the Boereoorlogstories series, edited by Jeanette Ferreira (2012) and also recently published by Tafelberg, whilst almost all the contributions are 'fictitious' as commonly understood, in volume 2 of 2012 one of them is actually a recreation of a historically factual experience. This is 1.Quoted from the St Helena Guardian, Jamestown, of 27 March 1900, in Johannesburg's Standard and Diggers' News (22 May 1900$)$.

2.Excerpt from 'An exiled Boer' by Ben J. Viljoen, Lieutenant-General Late Boer Forces, dated February 1906:8, and written in the Boer Settlement, Chamberino, New Mexico, as the preface to his An exiled General (see Viljoen 1906). 
Jan Horn's (2012) 'Die Goewerneur-Generaal van St Helena', which a note explains is based on a recollection of his own grandfather. Such reworkings and updatings of actual documentary material are also of special interest here.

Aware that no fiction writer may ever let historical facts get in the way of a good story, I nevertheless wish to record the following notes which have come to my attention, mainly on recent trips to St Helena and elsewhere, apart from the usual surveys of historical sites closer at hand and searches through sources in the usual repositories.

\section{Cronjé}

Pieter Arnoldus Cronjé was a direct descendant of the 17th century Huguenot Pierre Cronier and known as the Lion of Potchefstroom for his ability in organising commando actions, his membership of the Volksraad and eventually as commander-in-chief of the Republican forces on the Western frontier. There he was based on as many as half a dozen farms named Palmietfontein (not Palmietkuil as Loots would have it). These were along the Schoonspruit River with its bulrushes, north of Klerksdorp in today's North-West Province, which after all was the first of the old Transvaal's towns.

During his last decisive war his chief residence was never burned down, as his biographer would have it in volume 3 of the Dictionary of South African biography (Du Plessis 1977:185-187) and is often reported since, for it is still to be seen out on the Syferfontein-Eleazar route to the north, where the Brakspruit dirt road turns off to the left, as I confirmed on a recent recce. That is where his wife Hester (d. 1903) and he (d. 1911) are buried together in the Cronjé cemetery on private land.

Unlike the other two figures to be considered here, Cronjé did not write his own justification until late in life, with it being published posthumously in several episodes in the nowadays rather obscure Die brandwag in late 1913. There they remain largely unconsulted. By then, so utterly laid low and increasingly paralysed, he had certainly given up on having things his own way.

Yet in Loots's telling of the early life of this devout, staunch figure, he notched up several heroic defences of Boer interests, in his imagination, for instance, as a youth on the campaign against Makopane in 1854, rescuing his wounded older brother from those infested caves. Actually this was a valiant feat of stripling Paul Kruger, retrieving the corpse of the namesake of the future Potgietersrus, which in turn becomes the basis of Herman Charles Bosman's 'Makapan's Caves' story, first published in The Touleier in December, 1930 (see Bosman 1930, 1998). But Loots cleverly has Cronjé's factotum, Fenyang, emphatically denying that the old duffer was even present there then.

His decisive victories at Doornkop over the Jameson Raiders, his besieging of Mafeking and his winning strategies at the
Battle of Matjiesfontein, however, are a matter of record, hugely to his credit, though his reputation was to be damaged forever by his laager being cornered on the banks of the Modder River at Paardeberg. Having to capitulate in his mackintosh with stockwhip in hand, he stumbled under a white flag of surrender, with four thousand of the others still living, speechless with shellshock, his Hester behind him. The date was Amajuba Day, 27 February 1900, making the reversal all too significant.

It is this ironic scene, representing the first turn of the tide for the Boers into the power of the Brits, which is repeated over and over again in photos and artworks which journalists dispatched to the press worldwide.

Frank Brownlee, the future novelist then in his twenties, was a witness at the Battle of Paardeberg (currently Perdeberg). As part of the Cape Bearers company, he wrote letters back to his mother at this point. These describe the stench of piles of dead horses and oxen as Lord Roberts attempted to flush out the Afrikaner shelters in the riverbank, running up more casualties of his own men than on any other day in all of British military history (see Gray 2000). ${ }^{3}$

Loots uses this scene as her main event, since it was that surrendering, the taking off of his slouch hat, admitting defeat amid the smear of lyddite and the stench of carcasses, that he would have to re-enact twice daily for a living for months on end. In 1904 he became the star attraction in Fillis's monumental recreation staged at the World's Fair at St Louis, Missouri, which none other than Ben Viljoen was contracted to narrate, and which gives Loots her title.

Supporting Loots is a considerable amount of documentation, first advertised by Anna Smith, the librarian of the Johannesburg Public Library, in their Africana Notes and News (in December 1979), as available in their holdings. Since then Floris van der Merwe (2012) has assiduously amplified such resources, culminating in his well-illustrated The Boer War show in St Louis (1904), published in both English and Afrikaans in 2012.

Though Cronjé's intervening years held in isolation on St Helena are rather skimped in Loots - he hardly paddled and brooded on the volcanic island's sandy beaches, because there are none - yet there are some other vivid records of his imprisonment.

Firstly, on arrival he was still to stride up the main street as leader of his burghers. Secondly, he insisted on his right to have his guards mounted. Hence even today the island remembers how he would gallop from his luxurious quarters at the double-storeyed Kent Cottage up the Jamestown ravine, leaving his escort of flapping juniors behind in the pass. At Deadwood Camp he would attend to any complaints, whilst a multitude of Afrikaner exiles would applaud the arrival of his greenhorn British cadets, holding their rifles for them 3.The Brownlee letters are preserved in the National English Literary Museum, Grahamstown, South Africa. 
to assist them to remount. Because up there they had no mounting blocks, willing hands would bounce them right over their saddles. ${ }^{4}$

The sexagenarian's contingent of himself, wife Hester, his grandson and secretary, with their black servant raised by the family (Loots's wise Fenyang), was often enough photoed on kitchen chairs in the carriageway. Or he would pose alone in black on the wooden stoep, like the one at Palmietfontein, with pipe and coffee cup, doubtless sulking over how his very own brother had turned National Scout in order to capitalise on his losses. The notion that on his final return to South Africa from the United States of America (USA) in 1905, with a new wife, the widow of one of his casualties at Paardeberg, he would have recreated the elegant Georgian Kent Cottage out in the sticks seems unlikely, however.

Image-building of Cronjé in the USA had begun particularly with the first-hand accounts of the correspondent of The New York World, Howard C. Hillegas. In 1900 he had been an eyewitness at Paardeberg and published his With the Boer forces that same year. As if in defiance of the British take on the event, he delivered a full record of Cronjé's achievements, together with a likeable portrait. The following details were included: that he had 'a natural taste for things military', by studying 'foreign military methods and their application to the Boer warfare' (Hillegas 1900:186). And so 'deserting his peaceful stoep', he confronted the enemy out on the veld:

He rarely used a rifle, as one of his eyes was affected, but the short, stoop-shouldered, grey-bearded man, with the long ridingwhip, was always in the thick of a fight. (Hillegas 1900:195)

Supposedly impervious to bullets.

After an interview with the defeated frontiersman, Hillegas (1900:196) adds that he 'was not an extraordinary character, but urbane in manner and a pleasant conversationalist. Like the majority of the Boers, he was deeply religious ...'.

The other New York journalist to witness the submission of Cronjé and his entourage, including a translator, was H.F. Mackern. He followed their being escorted to the train which would transport them into exile, evidently with the tribute of salutes and bugle-blowings in honour of the fallen foe. Cronjé and his wife were both dressed 'in the plainest of homespun clothes, the general wearing the usual broad-brimmed hat of the Boer. He stands some five feet ten', writes Mackern (1901:60), 'is heavily built, with broad but somewhat sloping shoulders, a bushy beard covering the greater part of a face which had evidence of considerable strength of character'.

'It may not be uninteresting to mention here', Mackern (1901) adds:

what the Boer community think of Cronjé and his surrender. His stubborn resistance at Modder River, the awful punishment he inflicted at Magersfontein, his wonderful retreat from that

4.Only in A.J. Nathan's (1974) hilarious article is this aspect of Cronjé's life on St 4. Only in A.J. Nathan's (1974) hilarious article is this aspect of Cronjes life on St
Helena recorded, with several illustrations from Johannesburg's National Museum of Military History. stronghold in Paardeberg, all seem to be lost to them in that he did not entirely escape. The glories of his career are all brushed aside, and he is characterised as a 'bull-headed, obstinate old fool'. (pp. 60-61)

And Mackern gives the statistics: 4270 prisoners, as the British forces invade towards Bloemfontein, South Africa.

In such fashion Cronjé's last stand spurred a considerable range of written responses internationally, from tributes to his bravery to commemorations of his fall. For the poets' efforts in this regard, see especially M. van Wyk Smith's Drummer hodge of 1978. Nor should one omit to mention Etienne Leroux's wonderful novel, Magersfontein, O Magersfontein! of 1976, in which the veteran oudstryder has to convince his troops that the Highlanders in full garb, approaching them over the battlefield with bagpipes blowing, recreated for the movie version, must be picked off because they are not ostriches!

Also seldom consulted are the documents held in the archives of St Helena itself. There in January 2013, I was able to survey copies of the bilingual De Krijgsgevangene (Jamestown), printed in the office of the local Guardian from June 1901, in thirteen issues until the end of the year, although the venture never paid, for the last issue is written by hand. Edited mainly by $\mathrm{H}$. Everitt, it bore notices, for example, from LieutenantColonel R. Barclay, commander of the camps, concerning the censor's regulations (no political discussion or complaints over treatment, food supplies or criticism of the British government, troops and events). Yet De Krijgsgevangene did contain many gleeful reports of charitable events, smokers and other entertainments which their readers could only interpret ironically.

For example, how at one concert held for the benefit of the Boer hospital, 'Max de Kock's song "Poor Old Joe" (in character) with invisible chorus took very well, while A.B. Borcherds was receiving encores every night for his song "Baby".

Then in the second half the crowd-pleasing Christy Minstrels in blackface featured De Kock again as 'Tambo' and H. C. de Meillon as 'Bones' - an extraordinary demonstration of all the troubles they had, before joining the dance at the Masonic Hall. On the third night Captain de Witt Hamer closed the proceedings by thanking the public for their support and remarked on the cordial feeling which exists between the 'prisoners of war' and the inhabitants of the island, since they have learned to know one another. He concluded by wishing the inhabitants prosperity in the future (as in Number 8 of 17 August).

As a finale then of course:

our bearded "leading lady" attempted to elope in a small boat with a man from Rupert's Valley. Fortune did not favour them, and next morning the steam launch was sent in pursuit ... 
On 19 October a full-scale drama entitled A prisoner of war is reviewed, written to celebrate the birthday of their patroness, Queen Wilhelmina, with a cast literally of thousands.

The weekly St Helena Guardian itself published much material about the real POWs, which was occasionally picked up by Reuters or re-circulated in the press by other means; the first epigraph quoted above from The Standard and Diggers' News of Johannesburg is but one of many such instances. Letters and poems by the aspirant Boer bards were particularly welcome as column-stoppers, as in this unsigned and untitled lyric ([Anonymous poem] 1902):

$$
\begin{aligned}
& \text { Far across the boundless Ocean } \\
& \text { Where the sunset tints the West } \\
& \text { Stands a dainty little Island } \\
& \text { Like a sea bird in its nest. } \\
& \text { There within the old Plantation } \\
& \text { On the hillside where one treads, } \\
& \text { The Belladonna Lilies blush } \\
& \text { And droop their dainty heads ... (St Helena } \\
& \text { Guardian } 12 \text { June 1902) }
\end{aligned}
$$

(The tongue-in-cheek reference is to the dangling datura plant in bloom, those highly scented, poisonous moonflowers known locally as 'ladies petticoats' - the one garment not on view drying on the lines on washday at Deadwood.)

Another poem published in the St Helena Guardian on the same day is simply entitled 'St Helena from a POW's point of view':

$$
\begin{aligned}
& \text { Its worth has more than once been strongly proved } \\
& \text { In days of trouble when for safety sake, } \\
& \text { Old England's foes have had to be removed } \\
& \text { To where no further action they could take... }
\end{aligned}
$$

Now Peace has put an end to troublous strife, And bitter foes as friends quit the arena, We'll serve King Edward all our life And bid a fond adieu to St Helena. (Anonymous poem 1902)

A month later (on 10 July 1902) the St Helena Guardian even carries a poem by Colonel von Braun - Oberst of the party of recalcitrants, kept under close quarters at High Knoll Fort, currently restored as a tourist attraction. Haughtily he advises the locals: 'Search for Heaven in yourselves, and a life full of toil/ Will outstrip the luck you might find abroad!'.

With his colleague Adolf Schiel of the German Corps ready to publish his Sturm und sonnenschein in Südafrika in Leipzig in 1902, they depart with a makeshift salute to the Union Jack, before the next round of hostilities which were to commence in 1914.

Perhaps the best-known poem mentioning the St Helena experience was by the probationer poet, Jan F.E. Celliers, who with his son acted as the inmates' undertaker. Called 'Dis $\mathrm{Al}^{\prime}$, this famous imagist lyric, frequently reprinted, especially in Opperman (1978:39), contained the core lines: 'Dis ' $n$ ballingskap gekom / Oor die oseaan ... ', his bitterness exacerbated by chronic beriberi. Similarly, J.H.L. Schoemann had many songs like his 'Vaarwel!' published by Egeling's Bookstore in the Netherlands.

Neither is the major event on the island after the advent of Napoleon as a prisoner forgotten today. In his Poetic profile Robin Castell (2004:17) records a piece of doggerel called 'St Helena Boers': 'Old General Cronjé at their head / A broken man it must be said ...'.

His lavish St Helena: A pictorial treasury of the island of 2008 contains over a hundred reproductions of photos of the same prisoners of the period and in the local High School old Boer poems in English are still used in class as exercises for pupils to imitate (see Castell 2008).

Back then the prisoners' own intelligence services were hardly cut off from the world at large. For example, when the young C. Louis Leipoldt sailed on board the SS Persic from Cape Town, despite the fact that he did not put in at St Helena, he wrote a letter dated 07 February, 1902, to his fellow Pro-Boer, Anna Purcell. He confided that in his luggage he was smuggling material for the prisoners, which a contact in London would see to it was delivered there. ${ }^{5}$

A volume which includes the letters and other reports sent by mailship from St Helena the other way, principally to De kerkbode, is by the Dominee Abraham Faure Louw (1866-1960) (see Louw 1963). Twice he visited the island to become one of the leaders of the congregations amongst those prisoners of war. Noted for his missionary zeal in the camps, he travelled between them with his mobile pulpit, which became quite a feature there. He was once responsible for obtaining paroles for members of his church to attend large revivalist picnics in the countryside, under their banners enjoying plentiful bully beef and biscuits, and for students of his many classes he even gained permission for them to sit their School Higher exams in the late French Emperor's old drawing room at Longwood. He describes how post-delivery days were dreaded, with recipients of mail only too often having to visit the shops downtown for strips of black crêpe.

In his report of 10 September 1900, Louw (1963) notes that General Cronjé and his wife attended both his Sunday services, having visited him at Deadwood the previous Friday, yet he has difficulty in raising $£ 2.00$ in the collection with which to hire the Jamestown town hall for a week of morale-boosting meetings.

On 09 October 1901, he keeps account of another death amongst the inmates, soon to be augmented to over 6000, guarded by only one hundred English troops, with burials (of 3\%) on the Baptists' hillside at Knollcombes, for which the Saints contributed their half pennies towards a memorial plinth, held as a monument unto today. Louw's (1963) 5.See Margaret Cartwright (1976). The original letter is housed on the Cape Town campus of the South African National Library. 
harrowing account of his consolatory visit to the wards includes a note that Mrs Cronjé is not well, but recovering, whilst her husband's adjutant, François Labuschagne, is the one to succumb at age 55 .

Appealing for books for their growing library, which duly are donated mostly by Holland, Louw (1963) establishes a fund to purchase two typewriters at $£ 10.00$ each. When they are unpacked they occasion queues of learner secretaries of the future.

By March 1902, he notes that General Ben Viljoen has arrived without incident, occupying a house of his own with his adjutant, without having to stress that Louw and his fellow clergy chose rather to stay with their congregants, amongst the belltents and pondoks. All he remarks is that Viljoen's entrance triggers an outbreak of the worst illness of all, 'huistoegang-koors' (home-sickness) (Louw 1963:134).

Viljoen himself in his own record makes great show of not being able to sleep under quarantine in a tent with eleven others, lit by flares at night with incessant guard patrols of privates, or even in Blikkiesdorp, which had to be relocated monthly on account of damp. Rather he rents what he calls a 'little house' called Myrtle Grove, four hundred yards out of bounds, from a coloured landlady called Mrs Joshua (Viljoen 1903:286). By the time that magnificent documenter of the St Helenian exiles, Erich Mayer, came to depict Viljoen's residence in pen and ink, it had become nicknamed the three-storey 'Rose Cottage', that is to say the local Boer brothel. There Viljoen dictated his My reminiscences of the Anglo-Boer War, surrounded by pear-trees and donkeys (see Pretorius 2000:51). So Viljoen was hardly constrained 'with the chains of captivity firmly fastened to my ankles', as he maintains on the introductory page to his revised version, An exiled General of 1906.

An even more explicit record is Christiaan Kotzé's memoir, My ballingskap [My banishment], published as late as 1942 in order to supplement and even correct the records recuperated by and being made public by Bloemfontein's War Museum of the Boer Republics. Reviewing his own scrapbook of material accumulated during his years of internment on the island, when he set up as a salesman of 'Boer curios', and thereafter, he concentrates on the lot of callower recruits like himself. Born in 1881 and previously of Juta Street, Johannesburg, where he had worked in his father's bakery, he had been taken prisoner at the disastrous Battle of Elandslaagte, where it appears that Viljoen had actually deserted his commando so as to manage an escape. A future predikant and co-founder in 1938 of the Ossewa-Brandwag resistance movement against the perpetual British Empire, he was an astute indoctrinator who had even fewer words to spare for that other leader, Cronjé - except when some propagandist smeared the old man by accusing him of shooting two native women for having become too decrepit to work for him (Kotzé 1942:115). There Kotzé leapt to his defence. Otherwise he lists Cronjé baldly as the patron of one of their two-day athletic contests (three-legged races, potato-and-spoon, etc.), but mentions no more than that of him. For Viljoen, in a very full account, he manages nothing at all.

But when it comes to June 1902, and Cronjé standing on a wooden chest to break the news of the Peace of Vereeniging and advising the crowd no longer to cry over spilled milk (Kotzé 1942:122), Kotzé pledges to be one of the few committed not to take the oath of allegiance to the new English king, as all his generals recommend. Hence his transfer home is delayed for all of three months, with the real obdurate diehards not being shipped out until a year later.

None of these patriotic retrospects note either that once several prisoners resolved they wished to be on the winning side and were willing to return home to fight for the British, or could demonstrate that they had been commandeered unwillingly all along, a separate number two peace camp had to be established for them. In fact, animosity between the two factions grew so violent that loyalists and dissenters had to be let out on parole with their rations and kettles on different days of the week. A false alarm notice that peace had been achieved at home had the faithful mistakenly believe that victory was theirs, with riotous celebrations and the downing of all the island's champagne.

But on 01 June 1902, the sobering, true details were made known by cable. Cronjé was one of the leaders to be first at the Jamestown Court House to take the oath of allegiance, with his guard still protecting him, now from his victims who felt bitterly towards him as a traitor. As a sworn loyalist to Britain, with 470 like-minded others, he was out on the first ship, Union Jacks flying and the band playing 'Auld Lang Syne'. Viljoen followed him in July, leaving the bitter-einder rebels like Kotzé to the later chaotic departures. Some who were undecided like the Smith brothers chose to remain on the island, one of them having married a local even before the peace, with 1902 being a special year also for the reason that the Saints were celebrating the 400th anniversary of the island's discovery.

To commemorate this occasion, one Emily Jackson, who had introduced the Saints to pillow lace making for profit, published her Souvenir of Saint Helena: Pictorial and Descriptive. Then in 1999 to celebrate the centenary of the Boers' arrival the island's main contemporary historian, Barbara B. George (1999), the spouse of a descendant of one of the Smith brothers, extracted from it another locally published pamphlet, Boer prisoners on St Helena, which demonstrates how their residence there is celebrated to the present.

By 1905 Jackson had her fuller history completed, St Helena: The historical island from its discovery to the present day. There the arrival of the first contingent on SS Milwaukee, including Cronjé, towed ashore on wooden barges by a steam launch with some 500 others, is recreated with full pageantry. Thanks to the Governor's proclamation, the islanders' greeting is restrained and cordial, their newcomers' ragged march-past up the town's one street much photographed. 
Postcards of it are still issued at the Jamestown Museum, as if the ceremony had occurred only yesterday. There beneath the famous Jacob's Ladder, Boer handicraft skills are on display, as are portraits of Cronjé with his staff and grandson, seated alongside his wife, holding her hand. There are also models of that symbol of the Boer prisoners' recent mobility, the Trekkers' ox waggon, and his only defence besides God himself, the Mauser, obviously in effigy in wood only. Such money-making souvenirs have found their way into displays in every South African country museum as well, from walking sticks with carved horse's heads through to snuff boxes. Pieter Oosthuizen (1987) has listed all these curiosities.

\section{Viljoen}

The story of Benjamin Johannes Viljoen, a descendant of François Villion of Clermont, France, who had arrived at the Cape as a refugee in 1671, is not as easy to decode, since with his own fluent pen he had the habit of angling his life story according to circumstance.

His first publication was called De rebellie van 1895-96 in de Z. Afrikaansche Republiek, a 28-page pamphlet printed in Krugersdorp and published by Ons Volk where he worked as a columnist and newspaper owner-editor. Through to the end of his extraordinarily opportunistic career he would write such defences of his actions (in the above case merely arriving as a reporter behind Cronjé at Doornkop), culminating in his 'My life as a prisoner on the Island of St Helena', contributed (in English) to The Los Angeles Times's Illustrated Weekly (on 26 February 1916), fully a decade and a half after the event. Between these items he managed to produce one of the three most famous Boer War memoirs (alongside Kruger's own and General de Wet's), My reminiscences of the Anglo-Boer War (1903), focusing on the guerrilla war of 1900-1902, which became a bestseller in Britain after his promotional tour there.

Once he was in St Louis, Missouri, as ringmaster to Cronjé, he wrote and published there Under the Vierkleur: A romance of a lost cause (1904). In his 'To the reader' of this tale of Danie and Betty, he noted:

I have tried to present my characters as truly and characteristically as I could, without bearing either too much on their follies or their heroisms, the innate gentleness and simplicity of heart of their prototypes, or their general lack of those refinements of modern culture which the wide establishment of schools and systems of higher education alone can supply. For I come from a simple people, and of such I have tried to describe them. That I wrote it in English, instead of having it translated from my mother tongue, was solely for fear of losing by translation some of my real meaning. (Viljoen 1904:vii-viii)

A later translation of this version, dated La Mesa farm along the Rio Grande, NM, April, 1916, was to appear in Amsterdam after his roving commission as a Mexican consul touring the European health spas. In an article published in 1986, Michael Rice was to commend both versions for their avoidance of cheap effects.
Also there was the sequel to his My reminiscences of the Anglo-Boer War called An exiled General (Viljoen 1906), mentioned above, which was completed once he was settled at Chamberino, New Mexico. The proceeds were to be for the benefit and amelioration of the many irreconcilable and destitute Boer families emigrating to the USA from South Africa, including his own parents and four siblings, as well as one son of his first marriage, so poignantly described by Loots (2011). Granted that each item features our Boerbok at various events as the late Assistant Commandant General of the Transvaal Burgher Forces, he was nevertheless turning from a confessor pleading his own case into a fine historian.

As Blackwood's Magazine in Edinburgh noted in January 1903:

Not the least extraordinary result of the war in South Africa has been the quantity of literature to which it has given birth. With the termination of hostilities has come a new craze for war literature - a demand for the personal stories of the leaders of this pastoral people, who, for the last three years, have presented to the world the anomaly of a tiny nation maintaining armed defiance to one of the Powers of the World. (Anonymous review, p. 21)

This essay proceeded to review the anonymous On the heels of De Wet, as well as C.R. De Wet's (1902) own newly released Three years war

But Viljoen was not to miss out on such shouts: he mentions that none other than Winston Churchill had commended him on his bravery at Tugela River on 05 February 1900 (Viljoen 1906:61), or as in ex-president F.W. Reitz's poem celebrating his rescue of that 'Lady Roberts' along the railway line down which Kruger trundled into exile (Hoera vir Ben Viljoen). (The latter is quoted in full in an English version - see Viljoen 1903:181.)

Nor was Viljoen shy to quote the whole of the praise poem written in his honour, celebrating the same raid (and missed out in Van Wyk Smith), published in some 'Western paper' by one American Captain A.E. Lynch:

'It was a splendid feat of arms.'

Now 'that notorious Viljoen',

With a span of spanking mares,

Which erstwhile used to cleave the veldt ...

Come dashing down the donga Where the Maxim-Vickers lay,

Abandoned to th'advancing foe

And soon to be their prey. (Viljoen 1906:61-62)

And so on for another 37 spirited lines.

Viljoen also makes it known that President Teddy Roosevelt himself, a fellow member of the Dutch Reformed Church, had given the renegades an official welcome, with tugs hooting and spraying before them on their entry up the River Hudson. Aghast at New York City's skyscrapers, whilst mourning his own land's destroyed farmhouses, Viljoen made a point of forever quoting Roosevelt's endorsement (Viljoen 1905:952) of his 'strange tongue.' 
Evidently for Roosevelt, Viljoen represented the ideal of the untamed, virile youths and lusty horsemen out cowpunching and shooting Indians, which his friend Owen Wister had methodised into the immortal cowboy figure of popular entertainment (in The Virginian of 1902). Hence Roosevelt could dispatch Viljoen to do some frontier busting of his own - in New Mexico, which Viljoen would play a part in bringing in as the 47 th state in 1912. On his retirement from the presidency, Roosevelt himself embarked in turn on one of the largest game-shooting safaris ever held out in untamed Africa. Although it was for Viljoen a recurring cause of bitterness that the United States, like many other sympathetic countries, had not come to the rescue of the Boer Republics, it was Eric Rosenthal, the later biographer of De Wet, who in his Stars and stripes in Africa of 1938 made known that the Americans had supplied over 10000 horses and 8000 mules and donkeys during the conflict, in order to transport both sides.

Corroborating memoirs of all the activity during the guerrilla years of the youngsters in velskoens and tattered clothing, on horseback ducking armoured trains and the multiplying khakis filling the bushveld with machine-guns, blockhouses and barbed wire, were slow to appear, so that we may concede that Viljoen's achievements were under-recorded. For example, in Thomas Pakenham's standard history, The Boer War, first published in 1979, the hero who in a manifesto declared that with the resistance campaign it was now up to 'God and the Mauser' is missing from the central 300 pages, only to return as Wiljoen (Pakenham 1979:493).

But in 1964 the recollections of the Johannesburg-born troepie, Roland William Schikkerling (1964), at last appeared, edited by his widow, Mary Morison Webster, and published as Commando courageous: A Boer's diary. For two years in his early twenties he served in Viljoen's ranks, but seems not to have taken any note of his commander's own records. Hence Schikkerling (ibid:220) gives details of several events which Viljoen saw fit to omit: that his Hottentot servant, Mooiroos, mentioned merely as a 'Coloured groom' in Viljoen's reminiscences, 'always accompanied his master into battle ... and after each fight would give us his views and the reasons for the victory or defeat' (ibid:21); the several executions of traitors and non-combatants by firing squad (Viljoen admits to only one); and on the other hand the looting and casualties inflicted on them by indigenous tribes.

Schikkerling (1964) also gives summaries of Viljoen's inspiring major speeches, whilst also noting another missing piece of the picture - that at Pilgrim's Rest in late September 1901, he and Viljoen actually took the leads in a rollicking comedy about the trapping of a local family of girls at Dullstroom, their menfolk brushed aside as sell-outs. They closed with songs and a 28 stanza recitation (in English), with Viljoen providing the unrehearsed humour.

Once Viljoen is trapped near Lydenburg, with all his attendants shot dead so that they could give no testimony against him, he does not mention either that, as Schikkerling records, several attempts were made by his followers to rescue him. This does tend to suggest that possibly Viljoen staged his own capitulation.

Also amongst Viljoen's ragtag raiders in his late twenties was Dietlof van Warmelo, who was captured only to be transported to a POW camp in India. From there he published his On commando in July 1901 - that is, before his fellow internees' future was foreseeable and he could adjust his record to conform to later versions. Although it did not attract the mass attention of the subsequent reminiscences, once it was reprinted in 1977 one could note that he had had an entirely different take on the events he witnessed.

For instance, whilst recuperating on his uncle's farm near Marabastad, he recorded that Viljoen's commando arrived uninvited:

and stayed there a few weeks. The riff-raff of the commando are very unwelcome guests, for they do much mischief intentionally and thereby give the commando a very bad name. (Van Warmelo 1977:71)

As a result Commandant Kemp, now in charge of the Krugersdorp volunteers, breaks away from Viljoen 'because the latter had on a Sunday afternoon during service fired off several cannon-shots for the edification of a few fast women' (Van Warmelo 1977:72) - a disagreement upon which Viljoen, perhaps understandably, remains silent.

Although nowadays a main street with its Wimpy and Nando's in Lydenburg where he was subdued is called after him, one has to dig very deep in the archives to discover that in the Swaziland campaign of 1898 Commandant Viljoen declared the captured Bremersdorp stockade to be renamed in his honour (Fort Viljoen). Again, in December 1899, in Natal, he pillaged the coal-mining settlement of Newcastle, leaving the town hall erected to celebrate Queen Victoria's recent Diamond Jubilee in a shambles. Founded in 1854 and named after the then Secretary of State, the Duke of Newcastle, the town had been evacuated to avoid confrontation. Yet during their eight-month occupation it was to be known as Viljoensdorp.

How then did this soldier of fortune, in his invented uniform, his tunic braided and sashed, marooned on St Helena a thousand miles from anywhere, portray himself? In his My reminiscences of the Anglo-Boer War 'deprived of all my notes', he describes himself as 'a simple Afrikaner', 'laying no claim to literary ability' (Viljoen 1903:9). He is 34 years old, 'of middle height and build' (ibid:12). He claims that it is an 'irrebuttable fact' that it was from the Jameson Raid of New Year's Day, 1896, that may be dated 'the terrible trials to which our poor country has been exposed' (ibid:18). Not wishing to 'open old wounds' (ibid:19), it is nevertheless unexpected that as Field-cornet of the Krugersdorp Volunteer Town Guard he does not mention that it was he who insisted that the disarmed survivors of the invaders of Doornkop, lined up on the Market Square, should not immediately be executed. Rather they should obey Cronjé's order that they 
be marched to Pretoria for a fair trial. The last Viljoen (ibid:22) sees of Cronjé and his wife then is at Johannesburg station, on 29 September 1899, when the latter is off to take charge of the Potchefstroom burghers.

Two-and-a-half years later Viljoen (1903:22) is to meet up with the veteran once more on that Atlantic rock, 'a captive like myself, a broken old man', who had 'stubbornly refused to abandon his convoy and retreat' (ibid:65). 'But the English declare that all is fair in love and war', Viljoen adds tartly, 'and they ought to know' (ibid:38). Instead he nominates Christiaan de Wet, 'the world famous Commander of the Orange Free State, of whom all Afrikaners are justly proud' (ibid:49), as his preferred leader.

In the account following an interesting feature is how he takes to task A. Conan Doyle, whose several updated editions of his The Great Boer War (1902) were fast becoming considered the official history. Doyle himself, although he had left the country by the date of his enlarged edition marking the second anniversary of the war, had a certain admiration for Viljoen's feats of derring-do during the last winter campaign. Yet Viljoen (1903:131) finds several of Dr Doyle's prophecies of the outcome miscalculated, 'wide of the mark'. For a certain fake Commandant Erasmus who turns 'Pro-British', however, he reserves unconditional revulsion (ibid:153).

With regard to his own sincerity before the looming swearing to confirm a forced change of loyalties, Viljoen (1903) comments with regard to his own keeping of hostages:

We did not think it chivalrous to ask a man who was a prisoner to take an oath in return for his release. A prisoner-of-war has no freedom of action, so might have promised under the circumstances what he would not have done if he had been a free man. (p. 194)

Point well taken.

When, on 20 June 1901, Viljoen (1903:229) meets up with General de Wet at Waterval, to confer together with others of the elite leaders, he mentions only that De Wet was 'suffering acutely from rheumatism, but he showed scarcely any trace of his complaint, and was as cheerful as the rest of us'. No leaks of strategy then, for the sake of continuance of their ongoing crusade.

But then he is supposedly ambushed as we know, 'though it was a miracle that I was still alive, for a bullet had struck my chest, and would have penetrated had my pocket-book not stopped it' (Viljoen 1903:274) - a statement as dubious as it is transparent. This leads inevitably to 'most of us had never been on a ship, and only one of our number had ever voyaged away from South African [sic] before' (ibid:280), with landfall on 'The Rock' where another type of camp life begun on 24 February, 1902. Now practising the 'orderly and amiable demeanour' (ibid:287) that will serve him for the remainder of his aborted career, he is amongst 'our friend the enemy' (ibid:304). By June that year he has completed the manuscript which he will rework for the rest of his days.
Perhaps now the stage is set for the appearance of the real Ben Viljoen, rather than the battered showman - the showman who, having deserted his wife, remarried his landlady, settling on another Myrtle in this story - the widow Myrtle Dickinson in Missouri - but rather more privately than Cronjé, it must be said, who had the paying grandstands full for his re-betrothal; who, having cleared the ranges (the official term is pacified) of certain Indian tribes in Mexico, went on under a sombrero to overthrow a dictator there in a counter-revolution lasting only one year; and all that on horseback or in his Model T, suffering from asthma, crossing back over the border to supervise the alfalfa-growing on his estancia, Hope Harvest Farm, where his outsize onions became famous.

One sympathises with Loots for having cut back on the more sensational details of these feats, for they are all available in one of the very few sources she failed to trace, Basil M. du Toit's superb study, Boer Settlers in the Southwest, published by Texas Western Press in 1995.

Surely the most reliable source to cite here is C.J. Scheepers's chapter on 'Die Merkwaardige Viljoen', included in his Afrikaners in die vreemde (Scheepers, Krüger \& Trümpelmann 1976). Scheepers and his collaborators run through the familiar biographical markers: brought up in the Transkei, married Lenie Els in 1889, was running the weekly De Voortrekker in Krugersdorp before his election to the volksraad as the representative for Johannesburg. The quote from the Reitz poem is in place, the ambush, the repatriation from St Helena. On his return to the Cape Town docks, Scheepers notes, Viljoen ran into Generals Botha, De la Rey and De Wet, forming a committee to tour the continent, publicising the plight of their defeated countries so as to raise funds for reconstruction. Although Scheepers does not spell it out, clearly Viljoen was snubbed by them, making only a brief return home. In November 1903, he embarked on an international tour of his own (to Holland to retrieve his wife, to have tea in Britain with Joseph Chamberlain and so on). Thereafter: gringo; buried in the Masonic Cemetery, Las Cruces; his son Wynand serves in the signals during World War I - on the side of the Allies.

But what each and every one of these sources, including the astute Loots, miss out on in their attempts to heroise him, is the other story of the alternative Viljoen. The key to this omission is one Douglas Blackburn (1857-1929), the bachelor British pressman, socialist inclined, who in Krugersdorp entered into a partnership with Viljoen, whom he obviously considered a lovable rogue and charming deceiver. Their joint press syndicate ran from 1895, with the Englishlanguage The sentinel edited by Blackburn producing over a hundred weekly issues (in English), neck and neck from 1897 with De Voortrekker (in Dutch), staffed mainly by that opportunistic, womanising Viljoen.

Apart from being drinking-buddies, what he and Blackburn had in common was that they were outspokenly antiKruger, as was Eugène Marais's Land en Volk, to which for 
extra pennies Viljoen also contributed. Indeed, The Sentinel was soon closed down by the Pretoria hierarchs at the same time as The Star in Johannesburg, merely for the former to reappear as the bi-weekly The Transvaal Sentinel with its policy the same, 'only more so'.

A colleague of Blackburn's, the future literary historian Manfred Nathan (1944:112), later recorded in his autobiography that in Krugersdorp there was 'Viljoen, who started life as a Zarp or Republican policeman. We both knew him well. He was a friendly fellow, but rather mischievously inclined'. Nathan goes on to make the claim that Viljoen then became the one and only original of Blackburn's fictional 'Sarel Erasmus', the eloquent, unstoppable character who in Blackburn's hilarious satires made the poverty-stricken small dorps of South Africa famous the world over for their chicaneries and nifty double-dealing. The friendship between the apprentice Viljoen and worldly Blackburn surely must rank as one of the most productive in terms of South Africa's turn-of-the-century writings.

References to Viljoen in The sentinel and its sequel abound. To give an example, in one of the funniest pieces penned in the old Transvaal, called 'Midnight Entertainment' (published on 05 December, 1896), ${ }^{6}$ Blackburn describes the late arrival of Viljoen's fire brigade as the commercial block around the Central Hotel goes up in flames. Then a dog blocks the hose by standing on it, whilst at least they keep the inferno off the rose garden of that other Viljoen in town (no relation). He was the district surgeon qualified at Edinburgh University and St Bartholomew's hospital, London, who had dressed the wounds of the Jameson remnants. The suspicion of arson may not be dismissed.

Blackburn's favourite theme, with a wink and a nod towards Viljoen, was the inadequacy of unqualified bureaucrats appointed to official posts, who yet were compelled to improvise to compensate for lack of state salary. On 21 October, 1896, he had published the following editorial right under Viljoen's nose, with the heading 'An open letter to the junior state officials':

The greatest enemy to a country is a corrupt or indiscreet official. If he be detected and punished those who appointed him cannot escape the blame of his initial selection: if he remains in office the Government have to meet the charge of conniving at his rascality. (Transvaal Sentinel 6 May 1897, p. 4)

On the other hand, in his own memoirs, written jointly with W. Waithman Caddell and published in 1911, Blackburn expresses his admiration for Viljoen. Certainly he did not have to collect night slops for a living as Loots suggests, but with his field cornetcy was the equivalent in rank to lieutenant or magistrate. Blackburn notes that he always deferred respectfully in his Ons Volk to age, yet when he felt Kruger in the capital had blundered, he reserved the right to say so openly.

6.The selection of Blackburn's pieces in English in Africa of March, (see Gray 1978) includes fifteen items from The Sentinel and The Transvaal Sentinel, as well as the Blackburn-Blackwood correspondence quoted.
When Blackburn relinquished his post and left for the Golden City, turning their press over to its responsible editor, Viljoen wrote in his valedictory tribute (published in English in The Transvaal sentinel of 24 August 1898):

Whilst the editorial chair was occupied by that experienced journalist, Mr Douglas Blackburn, some excellent work was done in the direction of counterattacking the effects of exaggeration and misrepresentation too often indulged in by the Jingo organs. He also consistently opposed hypocrites and humbugs, fearlessly exposed shams and frauds and was never deterred by fear of consequences from criticising those in high places. (Gray 1978:66)

Soon, however, Viljoen abandoned the entire enterprise, basing himself later that year in Pietermaritzburg so as to spy out future enemy positions, inspecting its garrison at Fort Napier, where both his double, 'Sarel Erasmus', as well as his own character, the Taal-spouting Danie, would soon enough be held, putting their incarceration to good use by penning their respective books.

Once the war was declared Blackburn actually rode by invitation as a neutral correspondent for the British liberal press with Viljoen's own Johannesburg commando, witnessing Elandslaagte at first hand. After that Viljoen saw him off to Delagoa Bay in Portuguese territory, as he did with his own wife and offspring. Blackburn then rejoined the British at Durban and by December 1899, was present at the Battle of Pieter's Hill near Colenso, where he was wounded by shrapnel in his kidneys. This was an attack that was led by none other than Ben Viljoen.

Retiring to the remote Loteni Valley to recuperate, by the date of the peace accord Blackburn was lively enough to hammer out on his portable typewriter a letter to his publisher (on 04 July 1903), Blackwell in Edinburgh, reporting that his new novel with them - the middle one of a trilogy - was apparently selling well; he proposed that the 'man of the hour', his chaffcrony Viljoen on his brief return to Johannesburg, should be sent a copy for review (see Gray 1978:39) - at least before the military censors made away with it!

The situation Viljoen witnessed on his return convinced him finally not to change sides, even if it meant deserting his wife who had opted to collaborate. Loots (2011:72) suggests that an infidelity was involved in having their union dissolved, which is unlikely, but if so, surely the crime was committed on his side. Then when Tant Hester died (on 16 November, 1903), leaving Piet Cronjé destitute, the decision to take was easy: showbiz for dollars, as offered by Fillis, whose own circus business in South Africa had been ruined by the war. Not that his star performers would ever be paid out the promised fabulous sums.

Meanwhile Viljoen's alter ego, this so-called Sarel Erasmus, a true son of the soil always bleeding for his country - though never visibly - was left to appear in three fine Blackburn works. Initially he had been the scribe of his emigrant from the Cape father-in-law's story (in Prinsloo of Prinsloosdorp: A 
tale of Transvaal officialdom, first published anonymously in 1899; see Blackburn 1899). Then he recurs in the masterpiece which is his own story, A Burgher Quixote (Blackburn 1903), which covers his experience of the war. The follow-on $I$ came and saw, which as he records takes our tender-hearted naive right into a final learning experience in the heart of Edwardian London, was to appear in 1908.

Because it is hard to tell who the cod winner is in this delicately balanced in-joke between Blackburn and Viljoen, let it be noted here that Sarel is not exactly Ben himself. He is what Ben could have been, had he given in to the cowardice and panic he inevitably felt he had boldly to outface. In fact, Sarel is haunted by his 'old enemy' (Blackburn 1903:33) Ben throughout A Burgher Quixote, primarily for having crossed the border into Natal just before the outbreak of hostilities to escape them. Therefore, on whichever side of the frontier he is forced to act, he always finds himself on the wrong side. When first caught out ducking before the invaders, he confesses:

I had been ordered to join the commando of Ben Viljoen, who had just returned, having fought well at Elandslaagte and gone on to Johannesburg, where he was presented with a gold watch and made much of by the Burghers who had contrived to stay out of the fighting. Ben was a proud and haughty man, and puffed up with pride in that he had been raised from lowliness to greatness in a small space, and certain that he was better fitted to command the Boer forces than 'Slim' Piet Joubert. Ben was exalted in his own esteem because General Joubert had at last taken his advice, and invaded Natal against his own wish and judgment. But at the first war-council held at Sandspruit, Ben, who had a slippery tongue, had so worked on the feelings of the younger commandants that they had passed a resolution to cross the Border. This success pleased him very much, for he was a young man who had had much to do with Rooineks, and did not care to read in his Bible how pride goeth before a fall. (Blackburn 1903:33)

This resolution to invade, witnessed by Douglas Blackburn himself, is in Blackburn's view the one that was ultimately to lose Sarel's true people the war. Although Ben was proud of his knowledge of beginner's English, Sarel's first task meanwhile is to translate the mail pillaged from the Newcastle post office.

And so their enmity increases throughout this grand farce, with Sarel at each turn expecting to be discredited by his daemon, dodging with his smasher hat pulled ever lower over his sweaty forehead, until his only option is to escape the toing and froing into jail. In that refuge, like his progenitor, the master of lampooners Erasmus of Rotterdam (Blackburn 1903:4), he is able to recant and candidly take stock:

The mistakes I have made - and I admit there are many - will help the world to know the real character of my countrymen, among whom I have been as a Don Quixote, fighting on behalf of Great Britain against the folly and ignorance that have caused such loss and suffering. (Blackburn 1903:15)

So proceeds Blackburn's elegy for the idyllic, pre-industrial, pastoral way of life he favoured, with kind-hearted Sarel duped into submission at every turn, on whichever side he takes his stand, having to confront the rapacious and lethal 20th century. Once Blackburn's true-life old comrade is captured and compelled to be deported, that brings the rattling adventures Blackburn concocted for his humorous double to a halt.

Viljoen on his voyage out mentions seasickness as another hazard for the POWs when on board ship, but gives no further details. As the Norwegian Ingvald Schrøder-Nielsen (2012:65) wrote in his record, en route to the camps, in this case in the Bermudas, 'A month's journey across the Atlantic is no pleasure-trip when you are crammed together like animals in a kraal'. After a funeral at sea, he quotes the lament penned by a fellow transportee, Joubert Reitz, one of the half-Norwegian sons of the ex-president:
Is it not strange that such a man
who never before saw the sea,
should live upon it for a week,
then in it buried be,
his body lies beneath the wave
for all eternity. (Schrøder-Nielsen 2012:65) ${ }^{7}$

But the real Ben Viljoen disembarked at St Helena from aboard the SS Britannica with 39 other officers, almost two years after Cronjé. By that time his countrymen had undergone many profound changes. Not only had they improved their English and their cricket, but also set up numerous institutions, like Charles Taylor's Te huis offering sleepovers for 'vermoeiden reisigers' ['weary travellers'], where nowadays one may continue to indulge under its new name, the Star and Crown Pub. There was the nostalgically named Vierkleur koffiehuis with 'pannekoek altijd in voorraad' ['pancakes on hand'], with boerbrood and mosbolletjies a speciality as well, as advertised without translation in De krijgsgevangene.

They had also manually dredged the harbour front for tobacco money (1 shilling a day), not to mention reconstructed the entire landing stage, off which they skinny-dipped for hygiene and caught tuna, as Mayer has depicted (Mayer, in Pretorius 2000:45). Other work opportunities to raise funds included rat-hunting (1 penny per tail, rising to a tickey once their prey became rarer). Along 'Commissioner Street' up on the plain they had also constructed a commercial district out of biscuit tins, with every possible shop, including a photographic studio of their own.

Jackson (1905) also details the following, which to this day one would never have suspected from the usual accounts dedicated to sorrow and bitter suffering:

Among the prisoners were clever musicians, teachers, architects, builders, engineers, carpenters, cabinet makers, as well as steady labourers; and many of these obtained employment with the farmers and merchants, who were responsible for them during working hours. Camps were formed in the Government garden and in the Botanical Garden in town, so that they might live there after their day's work instead of return to their camps,

7.Published in an English translation only recently, edited by Lone Rudner and Bill Nasson, Schrøder-Nielsen's (2012) autobiography gives a detailed record of the underequipped and disorganised Western Transvaal post-Paardeberg. 
five or seven miles in the interior. But many of good conduct were allowed to find their own lodgings on condition that they were indoors at a certain time; others, such as shop assistants, bakers, grooms and household servants lived altogether at their employers' residences. (p. 111)

So cheers to the brass bands, competing with woodwinds on the parade ground under the antique Dutch fort.

Such is Jackson's description of some day-to-day events on their safe haven, which she observed and participated in, the indigenous population of just over 5000, including the garrison and shipping personnel, being outnumbered by their wily, spirited hostages.

Jackson (1905:153) even recorded that such was the impact of those Boer speakers that they left their mark on the Saints' dialect, with ' $\mathrm{v}$ ' becoming ' $\mathrm{w}$ ', as in whale for veil, Willie now Villie, and the 'th' tending towards ' $\mathrm{d}$ ' as in de, dis, dat which she considered, after all, as no worse than uneducated Londoners.

\section{De Wet}

Unlike the entries on Cronjé (Du Plessis 1977) and Viljoen (Krüger 1981) in the Dictionary of South African biography of 1981, in which the authors seem to reproach their subjects for their stagy failures, implying that their patriotism had been deficient, the entry for the Free State's Christiaan Rudolph de Wet (b. 1854) (Van Schoor 1995:233-240), the genius of bushwhackers, is all affirmative. Right there in volume 1 with that other canonised veteran general of the war, the Transvaal's Jacobus Hercules de la Rey, he holds his place untarnished. This is despite the fact that, in later life, as a signatory to the Peace of Vereeniging in 1902, he was yet to lead an insurrection against his own new country, in October 1914.

Saddling up with six of his own sons and other burghers old-style, he dared to take the magistrate of Vrede prisoner, creating mayhem there. He was only to be defeated by motorised Union troops at the Battle of Mushroom Valley, where he lost his promising son Danie. Tried for treason and held in the Johannesburg Fort for six months, his image as the grizzled rough-riding patriot with moustache and goatee, with bullet holes through his jacket, nevertheless persists as untouchably heroic in the literature. Even Celia Sandys, who has no time for Cronjie (her spelling), recently quoted her grandfather, Churchill, as describing De Wet admiringly as 'crafty in war and, above all, deadly cool' (Sandys 2000:192).

His is an unstainable reputation as an exemplary battler in the Afrikaans cause, the dashing hero of liberty and, as a guerrilla opportunist, an exemplary practitioner of anything but the rules of civilised warfare. Such is the version of De Wet also offered by Rosenthal (1949) in the biography General de Wet, and which persists in M.C.E. van Schoor's (2007) recent Christiaan Rudolph de Wet, Krygsman en Volksman.

He was of the sixth generation of the South African progenitor of the De Wets, who had emigrated from Amsterdam in the early 1700s, the sixth son of his father, after whom since 1880 Dewetsdorp in the east of the central Republic of the Orange Free State was named. One of his younger brothers (Pieter Daniel b. 1861), who had five sons and six daughters, as a Boer general and renegade, would notoriously turn coat, like Cronjés own brother, and scout for the invader, leading to a most famous Broedertwis or fraternal falling out between them. ${ }^{8}$

Christiaan Rudolph meanwhile in 1899 had eight sons and eight daughters of his own to support him, not to omit his indomitable mount, Fleur. He was a stutterer, which meant that in the heat of his numerous raids on British campsites, blockhouses, farmhouses and so on he had to use his sjambok to issue commands when his volunteers kept falling back.

The Free State de Wets were innumerable. Fighting in his ranks was also his nephew, Casparus Jan Hendrik de Wet, with four other such nephews who were to be held as prisoners in 1901 and taken to St Helena, together with a 15-year-old orphan De Wet and three of his brothers, one of whom perished there. Another nephew, Johannes Jacobus on his staff, is killed during their futile invasion of the Cape. During the campaign De Wet himself lists his own sons Kootie (Jacobus), Isaac and Christiaan Junior as penkop or stripling soldiers, as well as a Gert de Wet on his staff and another brother, Piet de Wet. Isaac was soon injured in action, whilst Kootie too was destined for St Helena... only to be reunited with his father when the shipment with Viljoen returned to Cape Town.

Indeed, the surname De Wet receives the most entries in all of the Dictionary of South African biography. Also for the record in Hans Fransen's (1982) Three centuries of South African art: Fine art, architecture, applied arts there is F.W. de Wet, known in the 1830s for the Cape's first wood-engravings of local scenes to illustrate almanacs and pamphlets; in the Companion to South African English literature (Adey 1986) there is Sampie de Wet (1906-1984), the short story writer who served during World War II in Italy in the Women's Auxiliary Services and recorded her battle experiences; then in Harold Jeppe's (1963) South African artists: 1900-1962 there is the renowned sculptress, Eone de Wet.

When Emily Hobhouse visited the De Wets in question, resettled on their farm near Koppies (on 01 July 1903), she wrote in a letter that there were 'many little De Wets and tonight they took out ping-pong and proceeded to play on the long table. They play very well. My favourite is Betty, aged eight' (Van Reenen 1984:218). When the old rehabilitated greybeard died on the next reconstructed farm called Allandale in 1922, after 48 years of marriage, he left 23 grandchildren and several more great-grandchildren. His widow was sustained on a Government pension for another 14 years.

In July 1902, once he was boarding the Saxon in Cape Town harbour, he did so as a member of that three-man peace

8.The vendetta between the De Wet brothers is especially covered in Peter Warwick's The South African War (1980), which stresses how counterproductive such a rift The South African War (1980), which stresses how counterproductive such a rift
could be to both warring sides. See Albert Grundlingh's 'Collaborators in Boer society' in Warwick (1980:293), where their photos are placed side by side. 
delegation, together with De la Rey and Louis Botha. Their objective was to raise funds to support those many widows and orphans who had been dispossessed by the recent hostilities. As honourable fighters who had not sold out, they could perhaps cold-shoulder the released Cronjé and Viljoen. Once De Wet in his cabin began writing his future justificatory bestseller, De strijd tussen Boer en Brit, Dominee Kestell helped him out with his High Dutch style. There it was on Cronjé and his pigheaded inability to evade cornering at Paardeberg - even with De Wet conspicuously opening an escape route for him - that the burden of blame for the following years of incremental failure falls. Viljoen meanwhile receives no mention at all, other than to be dismissed as a signatory to an early petition of May 1901, to save some lives by ceasing hostilities and seeking peace (see De Wet 1902:245). And little did the three-man delegation expect the rapturous reception they would receive first in Southampton.

With 'I am no book-writer', De Wet (1902) opens his preface to the English translation, which came out later that year with versions in five other languages. There his own judgement on the final years was touchingly as follows:

The whole world is convinced that, whatever the Boers might have done, England was determined to colour the map of South Africa red. And England succeeded beyond her expectations. For South Africa was stained with the blood of burghers and defenceless woman and children, and with the blood of English soldiers, who had died in a quarrel for which they were not responsible, and which could have been avoided. (De Wet 1902:196)

Yet this maniacal berserker continued his hit-and-run inroads and wrecking of rolling stock for loot, the ruining of neutral farms for cattle and horses, even when his commissariat was lost and ammunition and weapons were only to be had by pillaging the enemy or the so-called natives in their kraals, whom he treated repellently and rounded up as potential spies. For his blanket-sharing horsemen he could not provide clothing when they had to cross rivers into hostile territory.

By the end this devastated land was scorched by fire and reduced to a desert by locusts as well, and he himself had only one suit left to wear, with his papers and other documents lost over and over again.

Dedicated in an about-face to 'My fellow subjects of the British Empire', C.R. De Wet's (1902) Three years war certainly created a market for literature on the recent war, as the Blackwood's review noted. When all the brouhaha of contemporaneous reporting was over, it emerged probably as the most memorable text of all, surely for its cowboy vigour and never-say-die endurance of will, even though his cause - the maintenance of the independence of the two doomed Boer Republics of the 19th century - was lost as a foregone conclusion. With the next century's rise of the small nations globally resisting imperial domination, De Wet would come to be venerated. As Rosenthal (1949:178) notes on the last page of his biography, he was even to take his place at length in the British Dictionary of National biography, counted amongst the heroes of their Commonwealth of Nations.
If so, then it is predictable that C.R. De Wet's (1902) Three years war should be used as the standard source of many subsequent histories. In Rayne Kruger's Goodbye Dolly Gray: A history of the Boer War of 1959, for example, although all three of the main figures here (Cronjé, Viljoen and De Wet) receive major attention, it is the latter's record which is followed scrupulously and more than once quoted as an inspiration.

Whereas its status as classic is unquestioned, and his tomb at the Vrouemonument near President M.T. Steyn's may lie undisturbed, the Three years war nevertheless could do with some reinterpretation. Like many personal accounts to come after the First World War, it is a brutal work, almost incapable of expressing pity or fellow feeling. After an engagement, C.R. De Wet counts bodies, his own people's and the enemy's, as if statistics would sway the balance of power. He poses for studio portraits with a firearm and his fob watch on a chain, so that he will be recognised whenever he pounces. As an expert, he promises a second work devoted to the topic of scouting, but on that score he is outmanoeuvred by Baron Baden-Powell.

As a propagandist he uses all the tried and true distancing strategies, mostly by minimising the damage his frequent rampages may have caused and blaming others, scapegoating the responsibility for all atrocities. Whenever a setback occurs - like the capitulation of General Marthinus Prinsloo at the Brandwater Basin, with his men trooping into Fouriesburg and throwing down their rifles 500 at a time, in anticipation of the sea voyage to Broad Bottom, St Helena - De Wet pleads absenteeism. Then he gets off the hook of any charge of war crimes by stating, over and over again, that the other side was worse than any rebellious De Wet could ever have been. In the end this inability to shoulder any responsibility shows up a leader whose heroics were shallow and whose ethics unacceptable. Neither was his signed allegiance to his new country heartfelt and sincere.

What is more, he persists in portraying his people exclusively as simple rural frontiersmen, naive semiliterate Psalm-singers, devotedly herding their livestock way out on their veld, whilst repairing their waggons. He makes no mention whatsoever that he himself had been elected a Volksraad member, negotiating sophisticated customs treaties with and railways into the Cape Colony, and that his colleague and friend, President Steyn himself, was one of the finest rhetoricians South Africa had ever produced. Jointly they had managed Bloemfontein as a thoroughly modern city without a standing army, and its capture is mentioned only once in passing. But it was the stereotype of the hapless, pitiful backveld victim which became general, defining the term 'Boer' thereafter - a stereotype which Blackburn, for instance, had for years been scoffing at as demeaning and untrue.

Amongst the descendants of this heroic, world renowned De Wet - or at least so he claimed to be - was another who was to carry the family honour yet further. The name Oloff 
(various spellings) within the clan had been associated with the De Wet line since Olof Bergh of Göteborg, Sweden, married to Anna de Koning of mixed Dutch and Bengali descent, produced Christina Bergh, who married a Jacobus de Wet. For the Danish Asiatic Company in the Cape they acted as the first commercial agency to chandler butchered products and established an entrepôt on the Madagascan slave route. According to the entry for Johannes Carolus de Wet in volume 5 of the Dictionary of South African biography (Boucher 1987:195) several De Wet VOC officials used Olaf as a first name, possibly to advertise their part-Scandinavian origins. The figure to be dealt with here used Oloff de Wet as his surname. First name: Hugh.

My first acquaintance with this suspiciously named De Wet was when, in April 1977, I was scrabbling through the card catalogues in the Reading Room of the Harry Ransom Humanities Research Center of the University of Texas at Austin, not too far from the Tex-Mex border. Overlooking me was a lowering head and shoulders of it could only be an elderly Roy Campbell, the South African-born poet and swashbuckler. Before his death in 1957, I later discovered, Campbell (1985:564) had dedicated his Book-3 of the revised edition of his Flowering rifle, as recorded in his Collected works, to his 'heroic Ex-Enemy Hugh Oloff de Wet who flew for the Reds as a fighter pilot, and realised the truth before he finished'.

They had apparently first met up in Portugal after they had fought on opposite sides of the Spanish Civil War, as De Wet told a reporter of The Birmingham Post (see 'People's heads' of 14 March 1963):

But I was purely a mercenary for the Republicans. Campbell was a romantic who fought for the cause. I was a realist so I fought for the woman I loved. (p. 17)

Appropriately another of these Campbell busts is located in the City Library of his home town, Durban. Various Campbell biographies usually confirm that Campbell and this De Wet were party-going friends in London in the late 1940s, where De Wet maintained his sculpture studio. He specialised in portraits of poets, but Campbell's wife Mary also sat for him. He headhunted Ezra Pound after the latter's return to Italy as well, and also caught Dylan Thomas from the neck upwards for placing in the Royal Festival Hall.

The reporter on The Birmingham Post mentions (in the same item) that this noted London sculptor, Hugh Oloff de Wet, had also completed a head to mark the 50th birthday of John Gawsworth, the poet, for a New York gallery, although this seems untraceable. That news item ends with De Wet (1963:23) saying provocatively: 'Having been sentenced to be beheaded, I have a natural interest in people's heads. It's a great advantage to a sculptor - better than any art school'. More about Gawsworth, surely the last and worst of the Georgians, in due course. But was this De Wet merely a conman scoring off the name, making it all up as he went along, or for real?
The Harry Ransom Center could supply me with only the following on this apparent De Wet at the time from their 1968 'Faces of authorship' collection, in which they have many photos of the above sittings: born 1912 on Jersey, one of the Channel Islands, of the well-known South African family, father having an influential position at the British Navy base there; educated (in French) at the Institute Dupiche in Brussels, as was normal for Jersey citizens in those days, and at the Royal Military College at Sandhurst; author of The patrol is ended (the USA title of his Cardboard crucifix - O. De Wet 1938).

I figured that now that I was on the heels of this De Wet, I should track him down for an interview, stopping over in the United Kingdom on my return home. There his mother, Mrs P.W. de Wet, was supposedly living in St Albans, although this proved not to be so.

Many of the other details I picked up about him were questionable. Were the original South African De Wets really of Huguenot stock as he claimed, and descended also from Rembrandt's pupil, Jacobus de Wet? For spying had he actually been kept in solitary confinement in a strait-jacket by the Gestapo for two years, during which his wife had been tortured in front of him and committed suicide? Had he really lost an eye, tightly harnessed in his cockpit flying over Spain, with all hotel bills found and $£ 300.00$ for each of Franco's Falangist fighters downed? Did he wear an eyepatch?

Above all, there was his account of his part in the previous campaign in Africa, 1936, about which he claimed to have been one of two pilots recruited by Haile Selassie, the Emperor of Abyssinia as it then was. Reputedly his partner was the famous Herbert Julian, the so-called 'Black Eagle of Harlem', also employed to turn back the invasion of Mussolini in the one bomber of the Ethiopian Royal Air Force. Evelyn Waugh (1946) who was a correspondent there then makes no mention of any De Wet, and in Nicholas Rankin's (2003) biography of the South African-born journalist, George Steer, there for the press as well, he finds in Steer's records references only to the sensational Julian, with many photos in which no De Wet appears. De Wet said he quit near the inevitable end once Julian picked a fight with him and payment was not forthcoming. How did such harum-scarum daring and ducking all add up?

I had with me a report in The Star of Johannesburg, dated 10 February, 1941, in which he was described as Percy William Olaf [sic] de Wet. He had been sentenced to death by the German People's Court for sabotage and therefore should have been deceased long ago.

All I picked up in London was that the demise of this supposed descendant of our great Boer leader had occurred more recently. He had succumbed, aged 63, some two years before. The obituaries were generous, and particularly well remembered was how his World War II chronicle, The valley of the shadow (O.H. De Wet 1949), had been dramatised by the BBC. This detailed how, although they knew he was a trained artist: 
his guards had used his hands as ashtrays and broke his fingers. Yet he developed an impressive skill in sculpting bronze heads which are in collections all over the world. (The Daily Telegraph 21 November 1975)

There the trail petered out and I canned the story, returning it to the archives. This De Wet, I felt, if he was one, would be about the last offshoot the crusty old anti-British conservative patriarch, a founder of the National Party in 1914, would ever have wished to acknowledge anyway.

But then I received for review a pair of novels which do treat with this perplexing appendage of our national mythology centrally, including portraits of him taken from bookflaps (suit and tie, lavish moustache, no eyepatch), a portrait of him piloting his Niewport over bomb-damaged Spain, the report on 'Der fall de Wet' from Berlin's Beobachter of 03 February 1941, and even a portrait of his antecedent, Christiaan Rudolph, taken from Three years war (see C.R. De Wet 1902). Many other relevant clippings are reproduced within the text. So in the Mail $\mathcal{E}$ Guardian of 06 November 2009, in an article called 'Too hot to handle', I took the opportunity of sneaking in a reference to this unexpected discovery, in the hopes that some local genealogist might confirm the biological links to this literary aftermath of one of our steadfast braves (see Gray 2009).

Javier Marías is the author of these magisterial novels. The first was translated into English as All souls in 1992, and its follow-up called Dark back of time in English in 2001, and both have recently been reissued as Penguin Modern Classics (see Marías [1992] 2012; [1998] 2001).

Within a fictional framework they deal with Marías's years as a Spanish lecturer at Oxford University, his extracurricular love affair, his awkwardness as a foreigner and the sheer boredom of high table and so on. The second novel is a sort of reminiscential scrapbook, repeating and explaining, but also more deeply mystifying, the happenings of the first. Surrounded by boffins who know all in their disciplines, but seemingly nothing whatsoever about the outside world which they hold in their grip, our unnamed hero in a secondhand bookshop seizes upon the story of one who at least upped and off to become the King of Redonda.

As it happens, Redonda is another mid-Atlantic refuge, a tall skerry off Montserrat. It was first sighted by Christopher Columbus on his second voyage to the Caribbean of 14931496. For years a British possession, it is inhabited only by guano-producing sea-birds. Currently it is the third landfall of the independent state of Antigua and Barbuda. His longstanding friend Lawrence Durrell had the honour of the rank of the islet's Duke of Cervantes Pequeña being conferred on him by the exiled regent, who had inherited his estate, yet never visited it. His real name was Terence Ian Fytton Armstrong (1912-1970). Pen-name: John Gawsworth, who had published his collected poems in 1948 and really was a Fellow of the Royal Society of Literature.
If Hugh Oloff de Wet never caught the head of this particular poet, at least he was there the night the old codger perished to take his imprint in plaster, receding hairline and gangly moustache and all, to sell to the Society as a memento. Photos of Gawsworth alive in uniform with a cigarette between his lips, and of the gruesome death mask, appear back to back in both of Marías's fictions. With them Marías makes his watershed statement about heroic living and how its posthumous afterlife may be celebrated, being kept alive in the present.

And so may our repositories of memory, as in these three case histories, be researched and written over by creative writers such as Javier Marías through to Sonja Loots. They not only keep our records straight, but allow them to relive for us any researcher's literary pleasure.

Although other figures like Deneys Reitz have of course propelled Boer War literature in English into classic status, he has been excluded here (he was a mere stripling during the campaign, never a general, and did not publish Commando until 1929, once all the above had been well established). Besides, the three outlines above indicate that it was the reportage during and immediately after the field of action which did bring about the most enduring responses and their most creatively alive aftermaths.

\section{Acknowledgements Competing interests}

The author declares that he has no financial or personal relationship(s) that may have inappropriately influenced him in writing this article.

\section{References}

Adey, D., 1986, Companion to South African English literature, Ad. Donker, Johannesburg.

Blackburn, D., 1897, 'An open letter to the junior state officials', Transvaal Sentinel, 06 May, p. 4

Blackburn, D., 1899, Prinsloo of Prinsloosdorp, Dunbar Bros., Johannesburg.

Blackburn, D., 1903, A Burgher Quixote, Blackwood, Edinburgh.

Blackburn, D. \& Caddell, W.W., 1911, Secret service in South Africa, Cassell, London. Blackwood Magazine, January 1903.

Bosman, H., 1930, 'Makapan's caves', The Touleier, December.

Bosman, H. C., 1998, 'Makapan's Caves', Mafeking Road, Human and Rousseau, Cape Town.

Boucher, M., 1987, s.v. 'Jacobus Carolus de Wet', in C.J. Beyers \& J.L. Basson (eds.), Dictionary of South African biography HSRC, Pretoria, vol. 5, pp. 26-28.

Campbell, R., 1985, Collected works, vol. 1, Donker, Johannesburg.

Cartwright, M., 1976, 'C. Louis Leipoldt and Martial Law, 1901-02', Quarterly Bulletin of the South African Library 3(1), 17-24.

Castell, R., 2004, Poetic profile, Fish Hoek Printing \& Publishing, Fish Hoek.

Castell, R., 2008, St Helena: A pictorial treasury (1856-1947), Castell Collection, Fish Hoek.

De Wet, C. R., 1902, Three years war (October 1899-June, 1902), Constable, London. De Wet, O., 1938, Cardboard crucifix: The story of a pilot in Spain, William Blackwood, Edinburgh.

De Wet, H.O., 1949, The valley of the shadow, William Blackwood, Edinburgh.

'Der fall de Wet', Beobachter, 03 February 1941.

Doyle, A.C., 1902, The Great Boer War: A two years' record (1899-1901), Bell, London. Du Plessis, J.S., 1977, s.v. 'Pieter Arnoldus Cronjé', in Dictionary of South African Biography, vol. 3, HSRC, Pretoria, pp. 185-187. 
Durrell, L., 1969, 'Some Notes on My Friend John Gawsworth', Spirit of Place, Faber \& Faber, London.

Du Toit, B.M., 1995, Boer Settlers in the Southwest, Texas Western Press, El Paso.

Ferreira, J., (ed.), 2012, Boereoorlogstories, vol. 2, Tafelberg, Cape Town.

Fransen, H., 1982, Three centuries of South African art: Fine art, architecture, applied arts, Ad. Donker Publishers, Johannesburg.

George, B.B., 1999, Boer Prisoners on St Helena, Dax Richards, Jamestown.

Gray, S., 1978, 'Douglas Blackburn: Journalist into novelist', English in Africa 5(1), 3-72.

Gray, S., 2000, 'Invasion of the battlefields', Mail \& Guardian (suppl.), 11 February, p. 12.

Gray, S., 2009, 'Too hot to handle', Mail \& Guardian, 06 November, p. 23.

Guardian, 10 July, 1902.

Hillegas, H.C., 1900, With the Boer forces, Methuen, London.

Horn, J., 2012, 'Die Goewerneur-Generaal van St Helena', in J. Ferreira (ed.), Boereoorlogstories, Tafelberg, vol. 2, Cape Town.

Jeppe, H., 1963, South African artists: 1900-1962, Afrikaanse Pers-Boekhandel, Johannesburg.

Jackson, E.L., 1905, St Helena: The historical island from its discovery to the present day, Whittaker, New York.

Kotzé, C.R., 1942, My Ballingskap, St Helena, Nasionale Pers, Bloemfontein.

Krüger, D.W., 1981, s.v. 'Benjamin Johannes Viljoen', in Dictionary of South African Biography, vol. 4, HSRC, Pretoria, pp. 246-247.

Kruger, R., [1959] 1964, Goodbye Dolly Gray: A history of the Boer War, New English Library, London.

Leroux, E.,1976, Magersfontein, O Magersfontein!, Human and Rousseau, Cape Town. Loots, S., 2011, Sirkusboere, Tafelberg, Cape Town.

Louw, J. (ed.), 1963, Ds. A. F. Louw op St Helena, N.G. Kerk-uitgewers, Cape Town.

Mackern, H.F., 1901, Side-lights on the March: The experience of an American journalist in South Africa, Murray, London.

Marías, J., [1992] 2012, All souls, transl. M.J. Costa, Penguin, London.

Marías, J. [1998] 2001, Dark back of time, transl. E. Allen, Vintage, London.

Miller, J., (ed.), 1986, Voices against tyranny: Writings of the Spanish Civil War Scribner, New York.

Nathan, A.J., 1974, 'Cronjé's comic-opera guard', The Sunday Times Colour Magazine, 12 May, pp. 17-21.

Nathan, M., 1944, Not heaven itself: An autobiography, Knox, Durban.

Oosthuizen, P., 1987, Boer War memorabilia, Alderman Press, Edmonton.

Opperman, D.J. (ed.), 1978, Groot verseboek, 7th edn., Tafelberg, Cape Town.

Pakenham, T., 1979, The Boer war, Weidenfeld and Nicolson, London.

'People's heads', 1963, The Birmingham Post, 14 March.
Pretorius, C., 2000, Op St Helena - Vol van hartepyn: Die oorlogskuns van Erich Mayer, Protea, Pretoria.

Rankin, N., 2003, Telegram from Guernica: The extraordinary life of George Steer, war correspondent, Faber and Faber, London.

Rice, M., 1986, 'Camps, commandos and confessions', Lantern 35(3), 17-21.

Rosenthal, E., 1938, Stars and stripes in Africa, Routledge, London.

Rosenthal, E., c. 1949, General de Wet: A biography, CNA Dassie, Johannesburg.

Sandys, C., 2000, Churchill wanted dead or alive, HarperCollins, London.

Scheepers, C.J., Krüger, D.W. \& Trümpelmann, G.P.J., 1976, Afrikaners in die vreemde, Tafelberg, Cape Town.

Schikkerling, R.W., 1964, Commando courageous: A Boer's diary, Keartland, Johannesburg.

Schrøder-Nielsen, I., 2012, Among the Boers in peace and war, Africana, Cape Town.

'Sculptor jailed by Nazis dies', The Daily Telegraph, 21 November 1975.

Shadwell, B. [1902] 2008, Songs of the veld, and other poems, New Age Press/ Cederberg, London/Cape Town.

Smith, A.M., 1979, 'The South African Boer War Exhibition at the Louisiana Purchase Exposition, St

St Helena Guardian, 12 June 1902.

St Helena Guardian, 27 March 1900.

'St Helena from a POW's point of view', The St Helena Guardian, 12 June 1902.

The Star, 10 February, 1941.

Van der Merwe, F., 2012, The Boer War show at St Louis (1904), FJG, Stellenbosch.

Van Reenen, R. (ed.), 1984, Emily Hobhouse: Boer War letters, Human and Rousseau, Cape Town.

Van Schoor, M.C.E, 1995, s.v. 'Christiaan Rudolph de Wet', in E.J. Verwey (ed.), Dictionary of South African biography, vol. 1, HSRC Press, Pretoria, pp. 233-240.

Van Schoor, M.C.E., 2007, Christiaan Rudolph de Wet, Krygsman en Volksman, Protea Boekhuis, Pretoria.

Van Warmelo, D., 1977, On Commando, Donker, Johannesburg.

Van Wyk Smith, M., 1978, Drummer Hodge: The poetry of the Anglo-Boer War (18991902), Clarendon, Oxford.

Viljoen, B., 1903, My reminiscences of the Anglo-Boer War, Hood, Douglas and Howard, London.

Viljoen, B., 1904, Under the vierkleur: A romance of a lost cause, Small/Maynard, Boston.

Viljoen, B., 1905, 'Strange tongue', Century Magazine, April, p. 952

Viljoen, B., 1906, An exiled general, A. Noble, St. Louis.

Viljoen, B.J., 1916, 'My life as a prisoner on the island of St Helena', The Los Angeles Times Illustrated Weekly, 26 February.

Warwick, P., (ed.), 1980, The South African War: The Anglo-Boer War: 1899-1902, Longman, Harlow.

Waugh, E., 1946, 'A War in 1935', When the going was good, Duckworth, London. 